\title{
Impact Of Financial Reforms On The Banking System In Ghana
}

\author{
George Owusu-Antwi, Nova Southeastern University, USA
}

\begin{abstract}
The pre-reform policies, coupled with an acute and prolonged economic crisis which severely damaged the financial system in Ghana, caused policymakers to address the institutional deficiencies of the financial system through the Financial Sector Adjustment Program. This paper investigated the pre-and post-reforms policies to determine whether those policies have helped to eradicate problems that have hindered the effectiveness of the financial system. The liberalization of Ghana's financial system has included the relaxation of interest rate controls, credit ceiling, partial privatization of the government's own banks, restructuring of public sector banks, capital markets developments, and deregulation of the prudential system. The performance of the financial sector has been substantial and healthy since the reforms. Overall, the financial liberalization strategy pursued in Ghana has been supportive of wider economic development.
\end{abstract}

Keywords: Financial liberalization, prudential, regulations and deregulations and reforms.

\section{INTRODUCTION}

inancial liberalization is usually an important component of a country's strategy for economic
growth. The contribution of the financial reform to the economic growth of the country has been
enormous.

A major financial sector reform program has been implemented in Ghana since the early 1980s, involving financial liberalization and institutional reforms. Financial reform became necessary because the prereform policies of the government of Ghana over financial markets, together with an acute and prolonged economic crisis, had severely damaged the financial system, leading to both financial unpredictability and bank distress (Aryeetey and Kanbur, 2005). In 1989, the Financial Sector Adjustment Program (FINSAP) was started and supported by the Financial Sector Adjustment Credit (FSAC) from the World Bank. The objectives of the FINSAP were to address the institutional deficiencies of the financial system, in particular by restructuring distressed banks, reforming prudential legislations and the supervisory system, permitting new entry into the financial markets by public or private sector financial instruments, and developing money and capital markets.

The purpose of this paper is to investigate whether the financial liberalization has helped in eradicating or mitigating the problems that have undermined the effectiveness of the financial system. To this effect the paper reviews the pre- and post-liberalization policies and their impact on the banks' market structure. In order to judge the implications of these changes in the banking sector, the nature and the performance of the banking industry is examined. The next section of the paper explores the problems faced by the financial sector in Ghana prior to the reform period. The following sections analyze and assess the major reforms that have taken place over the past decade, the impact of these reforms, a brief presentation of Ghana's banking structure, banking sector performance, policy discussion, and evaluation of the reforms. The final section presents the conclusion of the paper. 


\section{PROBLEMS BEFORE THE REFORMS}

The inability of the financial system in Ghana to deliver effectively financial services has prompted policymakers to reform the financial system (Aryeetey, 1996). In the late 1980s and early 1990s, Ghana experienced considerable macroeconomic turbulence. Inflation rates during these periods were high and volatile, which reflected the difficulties in controlling the budget deficit as well as rapid monetary expansion. The high rates of inflation together with excessive devaluation eradicated much of the share capital of banks in real terms. To this effect, the banks in general faced a difficult macroeconomic environment that served as a trigger to banking crises (Daumont, Le Gall, and Leroux, 2004).

In addition to various structural and institutional constraints, the financial system had been rendered ineffective by the control regimes that different governments had erected, with a view to ensuring that financial resources flowed to sectors which public officials believed were more deserving. But the control regimes ensured that the financial markets no longer functioned, while the repressive environment reduced private participation in the organization of financial services. This had been done by placing restrictions on entry into banking, increasing public ownership of major banks, the employment of high reserve requirements on deposits, and the placing of ceiling on lending and deposit rates. This led to a lack of competitive environment market inefficiencies, and political patronage in the banking system (Johnston and Brekk, 1991).

During the Acheampong regime (1972-1978), for example, all the commercial banks had a substantial state shareholding, and the large part of their loan books were subjected to state-owned enterprises. This heavy state control implied that many banks became the instruments for channeling funds to highly inefficient and corrupt state-owned enterprises. In addition, loans were also granted to military officers without any prior assessments of their competency to repay back the loans. Under that regime, banks had no other choice than to comply (Leith and Söderling, 2000). According to Leith and Söderling, about 92 percent of the banks' credit that were outstanding was to the public sector, which was granted on political grounds and not on any business criteria.

Unlike the U.S. financial system, characterized by private ownership of financial institutions, all financial institutions, with the exception of two foreign majority-owned banks, were owned by the government. This has led to the lack of a competitive environment, market inefficiencies, and political patronage in the banking system. A major consequence of the government's ownership of banking institutions is the control and regulation of interest rates, which distorted the allocation functions of interest rates in any market economy (Ziorklui, 2001). A study by Micco, Panizza, and Yanez (2007) used a new data set to reassess the relationship between bank ownership and bank performance and tested whether politics also play a vital role in this relationship. They found that state-owned banks operating in developing countries tend to have lower profitability, lower margins, and higher overhead costs than comparable private banks.

La Porta, Lopez-de-Silanes, and Shleifer (2002), claim that state-owned banks are inefficient because they are captured by politicians who are only interested in maximizing their personal objectives. Clarke, Cull, and Shirley (2005) provide reasons why state-owned banks might perform worse than private banks; a major reason is that state-owned banks face less competition than private banks. To that effect, they are unable to compete in competitive markets and, to some degree, acquire subsidies from the government to cover their losses. Toward this end, state-owned banks might have more branches, higher deposit rates, and lower lending rates than their rivals, because they can cover losses through government subsidies. Rather than using restrictions on competition to reduce the need for subsidies, the subsidies undermine market competition.

The purpose of banking regulation and supervision is to ensure that the banking system as a whole remains sound (Folkerts-Landau and Lindgren, 1998). Banking laws and regulations seek to promote policies that allow only financially sound banks to operate; limit excessive risk-taking by owners and managers of banks; establish appropriate accounting, valuation, and reporting rules; and provide for corrective measures and restrictions on activities of weak institutions. Bank supervisors on the other hand monitor the soundness of the banking system, the adequacy of banks' risk-management practices and financial data, and compliance with prudential regulation (Daumont, Le Gall, and Leroux, 2004). 
According to Daumont, Le Gall, and Leroux (2004), the Banking Act of 1970 in Ghana did not provide sufficiently clear guidelines to banks and the banking authorities on, inter alia, minimum capital requirements, risk exposure and prudential lending limits for banks, provisions for possible loan losses, and methods of interest accrual on nonperforming loans. Banking supervision, therefore, was beset by numerous problems, starting with poor organization. Off-site supervision was minimized by deficiencies in information, and on-site supervision was typically erratic. In many cases, regular reporting systems were not in place, and data were lacking. It was not until 1988 that the Banking Supervision Department started carrying out on-site inspection. They were heavily depending on banks' internal control mechanisms and external auditors' reports to analyze and assess bank performance (Leith and Söderling, 2000; World Bank, 1986). According to World Bank and to Leith and Söderling, the Banking Supervision Department had serious staffing limitations. There were a few specialized, skilled, and qualified examiners who even lacked adequate training. The World Bank added that the low civil service salary levels made it difficult for banking supervision departments to attract and retain qualified examiners.

The lack of adequate prudential regulatory enforcement and supervision of commercial banks has been a major cause of problems in Ghana's banking sector during the 1970s and early 1980s. In the absence of vigorous enforcement of prudential regulations as well as effective bank supervision, less attention was paid to the provision of required reserve and capital requirements. The consequences have been the insolvency of many banks in Ghana. The regulatory and supervisory areas of the banking sector have been acknowledged to be poor and have led to many difficulties encountered by the banking system (Popiel, 1994). According to Popiel (1994), the poor regulation and supervision can be partly blamed for the large number of nonperforming assets, found on the books in the 1970s and 1980s. Popiel explains that the enforcement of banking regulations had been ineffective due to the fact that supervision had tended to focus only on the condition of banks at a point in time, instead of strengthening management systems. Ziorklui (2001) indicates that regulation and bank supervision in developing countries should emphasize compliance with monetary policy and foreign exchange guidelines. Additionally, the goal of bank supervision should be to encourage the promotion of the banking sector's safety, stability, and efficiency.

Podpiera (2004) investigated the relationship between compliance (with Basel Core Principles for effective banking supervision) and banking sector performance, as measured by nonperforming loans and net interest margins. He indicated that higher compliance with Basel Core Principles improves banking asset quality significantly, even if one controls for the country's level of development and the macroeconomic setting. Nonetheless, Podpiera's study did not take the openness of competition into consideration. Mattoo, Rathindran, and Subramanian (2006) examined the effects of financial liberalization on per-capita GNP growth in 59 countries between 1990 and 1999. They found a positive relationship between financial sector openness and economic growth. They indicated domestic market competition, foreign ownership, and limited controls as the key elements of financial openness. However, these elements were lacking in the Ghana banking system.

The financial condition of a bank, however, depends on reliable estimates and well-designed accounting principles. Clear standard and accurate information are important so that managers can make decisions that are conducive to sound banking systems. The accounting and disclosure standards in practice were very weak. There were no standard accounting principles prior to the banking crises. In essence, there were no required formats for balance sheets, and the regulatory body failed to enforce prudent accounting standards. The lack of uniform accounting standards led to inadequate loan loss provisions as well as reserves (Daumont, Le Gall, and Leroux, 2004).

A major part of the continuing problem is that financial sector reforms have focused too narrowly on the elimination of financial repression through price and interest rate liberalization. Nissanke and Aryeetey (1998) argued that reform in countries like Ghana had not dealt adequately with structural and institutional issues which have been confronting the financial system as it focused mainly on the policy matters. The banking system has also failed to mobilize resources for growth and development, as well as failed in its supportive role in the development of the monetary sector. The failures of the system were reflected in how various policies had become dysfunctional and were often ignored in the operations of the institutions. 
The efficiency of the banking system's operation is also constrained by the Ghanaian economy's technological underdevelopment as well as information asymmetry (limited information). Unlike the United States where automation and the use of computers have increased the productivity and efficiency of bank employees, the production of banking services in Ghana is labor intensive; bank ledgers, customer accounts, and other records are still processed by hand. This has led to low productivity, underutilization of human capital, and inefficient operation in the banking sector. In view of these inefficiencies, which result in a considerable amount of waiting time at the banks, a large section of the Ghanaian population prefers to hold liquid cash outside the banking system (Aryeetey and Kanbur, 2005).

The low level as well as inefficient financial intermediation in Ghana can also be accounted for by the absence of a competitive structure (Buchs and Mathisen, 2005). According to Buchs and Mathisen, there is still no one-to-one relationship between concentration and competition in the banking sector. They explained that monopolistic or oligopolistic behavior has tended to result in a higher intermediation cost and diseconomies of management than would be the case under a competitive structure.

By the beginning of the 1980s, most banks needed recapitalization after years of poor asset management and nonrepayment of loans given to state-owned enterprises. After 1983, the solution to the problems for the new policymakers was the adoption of a more liberal stance. Aside from everything else, liberalization was considered to be necessary to obtain the international assistance needed to finance balance of payments and budget deficits. There are indications, however, that neither the repressive nor the liberal approach has improved substantially the financial sector's ability to support socioeconomic goals (Aryeetey, 1996).

According to Aryeetey, the new policy and legal environment has stimulated the entry of a variety of both banks and nonbank financial institutions (NBFIs). Indeed, the new NBFIs have introduced a wider variety of financial products to compete with commercial banks, which have, at best, only re-packaged their traditional financial products of current accounts, savings accounts, time deposits, and a selected number of bonds and bills. However, the formal NBFIs are competing largely for the same large-scale clients of the commercial banks with relatively little impacts on broadening the range of clients with access to formal financial services. Aryeetey and Kanbur (2005), observe that the reforms in the sector have not led to significant restructuring, thus leaving the sector incapable of leading private sector development. They explained that the inability for the banks to develop more innovative and competitive approaches to deal with the demand for financial services is another major factor hindering the sector's development. What is crucial is for the sector to make a more meaningful impact on growth and development.

Despite the ample reforms that have taken place in the financial system, the banking systems are grossly inefficient, illiquid, and febrile (Aryeetey and Senbet, 2004). Buchs and Mathisen (2005) claim that the structure, as well as the other market characteristics, has constituted an indirect barrier to entry into the Ghanaian banking system, and as a result serving to shelter the large profit of the banks. They presented an overview of Ghana's bank sector in which the three largest banks account for 55 percent of the total assets of the banking system. They identified the following factors as key obstacles to competition: persistent financing of government needs to the detriment of the private sector, high investment cost, and barriers to competition on interest revenues and losses on the loan portfolio. To improve financial intermediation, Buchs and Mathisen recommended an effective fiscal adjustment and a rigorous enforcement of creditor rights by addressing institutional lapses in financial regulations and judicial reviews of Ghana's legal structures.

Steel and Andah (2005) took a different approach to discuss how to make the sector more effective. In analyzing and assessing how policy, legal, and regulatory framework for the sector have been affected and been influenced by the development of rural and microfinance institutions (RMFIs) in Ghana, particularly in terms of the range of institutions and products available, their financial performance and outreach, Steel and Andah argued that the adoption of business rules on different tier bases reflect Bank of Ghana's growing understanding of RMFIs and NBFIs. They discussed the extent to which a flexible regulatory environment can encourage innovation, while the diversity of RMFIs and products can serve different market niches not reached by commercial banks. 
Steel and Andah (2005) also considered the point at which special legislation may be needed: whether to facilitate commercialization and sustainability of the rural and microfinance (RMF) industry or to protect deposits and ensure the stability of the financial system. However, while Ghana's approach has fostered a wide range of both formal and informal RMFIs, it has not as yet been very successful in achieving strong financial performance, significant scale, and true commercialization of microfinance. Steel and Andah (2005) observed that maintaining the different tier system requires substantial investment in the Apex Bank, in supervision and training, and in strengthening the capacity to make good use of the liquidity being released. In sum, the biggest hurdle lies in finding the right balance between ease of entry for greater outreach, prudential regulations to enhance sustainability, and monitoring capacity.

The poor reach of financial services is further highlighted in a contribution on savings by Quartey and Blankson (2005). They discussed the issue of poor mobilization of resources in an unstable environment and argued that, despite the reform, including financial sector liberalization, Ghana still experiences low savings. They attributed this to a combination of micro- and macroeconomics, as well as the political factor. What really matters for the net effect on competition, according to Buchs and Mathisen (2005), is the level of contestability in the market. The threat of potential competition or lack of competition can considerably affect competitive conditions, regardless of market concentration. By regional standards, bank concentration in Ghana appears to be moderate and it is the principal state-owed banks that enjoy a considerable market power with 20 percent of the total deposits and 44 percent of the total branches. This is a situation that may influence price setting among banks and distort competition.

\section{FINANCIAL REFORM POLICIES IN GHANA}

\section{Pre-Reform Financial Policies}

Ghana's financial sector after post-independence was characterized by extensive government intervention. The banks that were founded between the early 1950s and the late 1980s were majority- or whollyowned by the public sector, while the government also acquired minority shares in the two already-established foreign banks in the mid-1970s (Brownbridge and Gockel, 1996). According to Brownbridge and Gockel, financial sector policies were characterized by severe financial repression, real interest rates were steeply negative, and most of the credit was directed to the public sector.

The government set up its own commercial and development banks to provide access to credit for indigenous business and farmers, who had been denied access to credit by the foreign commercial banks. To this effect, the Ghana Commercial Bank (GCB) was established in 1953 to improve credit of lending facilities. The GCB was also instructed to extend branch network to rural areas so the people who are heavily indulged in both subsistence and commercial agriculture will have access to banking facilities. The GCB grew to become the largest bank in Ghana, with 36 percent of the total deposits in the late 1980s (Brownbridge and Gockel, 1996).

The government also acquired 40 percent of the equity stakes of the two foreign-owned banks, Barclays Bank and Standard Chartered Bank (SCB), which were established during the colonial era. This was the result of the indigenization decree that was enacted in 1975. The National Investment Bank (NIB) was set up in 1963 to provide long-term finance for industries. In 1965, the Agricultural Development Bank (ADB) was also set up to provide credit facilities to farmers and stimulate agricultural projects. In 1972, the Merchant Bank Ghana (MBG) was established as a joint venture between ANZ Grindlays, the government, and public sector FIs, with the first having a 30-percent stake. To provide loans for housing, industrial construction, and companies producing building materials, the Bank for Housing and Construction (BHC) was also established in 1974. The Social Security Bank (SSB) was founded in 1977 and grew rapidly to become the second largest bank in Ghana, with 18 percent of deposits in the late 1980s. The objective behind this establishment was to provide credit to include longer term loans for businesses and consumers. It also invested in the equity of several large businesses.

The National Savings and Credit Banks (NSCB), formerly the Post Office Savings Bank and the Cooperative Bank, were also established in 1975 to provide consumer loans, and credit for small industries and cooperatives (Adjetey, 1978; Brownbridge and Gockel, 1996). There is an idea that government-owned banks in 
developing countries are less profitable than private banks. La Porta, Lopez-de-Silanes, and Shleifer (2002) found that, in developing countries, the presence of government banks tend to have a negative effect on growth. They argue that developing countries are not highly equipped to deal with the distortions that arise from the government ownership of banks. As compared to high-income countries, Micco, Panizza, and Yanez (2007) argue that banks in developed countries ceased to play a development role and merely mimic the behavior of private banks, whereas in developing countries, public banks still play a development role which undermines their profitability.

\section{Interest Rate Policy}

Interest rates were administratively controlled by the Bank of Ghana (BOG). The rationale for the controls was that credit had to be cheap so as to promote investment and support that favors borrowers (Daumont, Le Gall, \& Leroux, 2004). It was the BOG that determined the structure of the bank interest rates, which include the minimum interest rates for deposits and maximum lending rates. Preferential lending rates were given to priority sectors such as agriculture. The structure of interest rates determined by the BOG made no allowance for loan maturity or risk; indeed, incentives for banks to extend credit were often perverse because riskier sectors such as agriculture were accorded preferential inflation rates. In most of the years, nominal interest rates were held below the prevailing inflation rates. However, when inflation escalated in the middle of 1970s and the early 1980s, real interest rates were highly negative (see Table 1 below).

\section{Credit Controls}

Governments in a number of countries have sought to influence the allocation of credit directly with varying degrees of control (Daumont, Le Gall, \& Leroux, 2004). In Ghana, the BOG was responsible to set up credit guidelines which forced the banks to provide credit facilities to the key areas of the economy such as agriculture, manufacturing, and export. The sectoral credit directives were not strictly enforced. However, additional regulation stipulated that lending rates for agriculture should comprise a minimum of 20 percent of the total loans, with shortfalls to be transferred to the ADB. Foreign companies were required to obtain BOG's permission to access loans from domestic banks (Brownbridge \& Gockel, 1996).

Table 1

Selected Interest Rates and Inflation: 1975-1995 (\%)

\begin{tabular}{|c|c|c|c|c|c|c|}
\hline Year & $\begin{array}{l}\text { 12-Month } \\
\text { Deposits }\end{array}$ & $\begin{array}{l}\text { Savings } \\
\text { Deposits }\end{array}$ & $\begin{array}{l}\text { Lending } \\
\text { (agric.) }\end{array}$ & $\begin{array}{l}\text { Lending } \\
\text { (other) }\end{array}$ & TBS & Inflation \\
\hline 1975 & 8 & 7.5 & - & 12.5 & 7.8 & 18.8 \\
\hline 1976 & 8 & 7.5 & 6 & $11.5-12.5$ & 7.8 & 55.4 \\
\hline 1977 & 8 & 7.5 & 8.5 & $11.5-12.5$ & 7.8 & 116.5 \\
\hline 1978 & 13 & 12 & 13 & 18.5 & 12 & 73.1 \\
\hline 1979 & 13 & 12 & 13 & $17.8-18.5$ & 12 & 54.5 \\
\hline 1980 & 13 & 12 & 13 & $17.5-18.5$ & 12 & 50.2 \\
\hline 1981 & 19 & 18 & 20 & 25.5 & 18.5 & 116.5 \\
\hline 1982 & 9 & 8 & 8 & 14 & 9.5 & 22.3 \\
\hline 1983 & 12.5 & 11 & 12.5 & 19 & 13.0 & 122.8 \\
\hline 1984 & 16 & 14.5 & 16 & 22.5 & 16.8 & 39.7 \\
\hline 1985 & 17 & 15.5 & 18 & 22.5 & 16.8 & 10.4 \\
\hline 1986 & 20 & 18.5 & 22.5 & 23 & 19.8 & 24.6 \\
\hline 1987 & $20-22$ & 21.5 & $22.8-30$ & 26 & 19.6 & 39.8 \\
\hline 1988 & $17-22$ & $17-21.5$ & $23-30$ & $23-30.3$ & 19.8 & 31.4 \\
\hline 1989 & $12-20$ & $15-19$ & $22.5-30$ & $22.5-30.3$ & 19.9 & 25.2 \\
\hline 1990 & $14-22$ & $14-18$ & $22.5-29.5$ & $22.5-30.3$ & 27.5 & 37.2 \\
\hline 1991 & $16-24$ & $10.6-19.5$ & $19.5-31.5$ & $23.5-31.5$ & 18.0 & 18.0 \\
\hline 1992 & $15.5-22.5$ & $11-16$ & $19.8-26.5$ & $24-29$ & 25.4 & 10.0 \\
\hline 1993 & $17-32$ & $15-22.5$ & 24-39 & 26-39 & 32 & 24.9 \\
\hline 1994 & $14-31$ & $13.8-22.5$ & $22.5-35.5$ & $29-37.5$ & 29.5 & 24.9 \\
\hline 1995 & $18-34$ & $21.5-31$ & $27-38.5$ & $32-40.4$ & 33.0 & 38.5 \\
\hline
\end{tabular}

Sources: Gockel (1995, p. 320); Bank of Ghana (various issues). 


\section{Demonetization Exercises And Antifraud Measures}

In the late 1970s and early 1980s, the government took a series of measures to reduce the money supply and inflation. The most drastic measures were the currency appropriations in 1979 and 1982 in which the banks were ordered to furnish information to the authorities about customers at the authority's request. In addition to this, customers who held any account in excess of 50,000.00 cedis were frozen, pending the authorities' investigation for fraud or tax liabilities. Accordingly, bank loans for financing of trade inventories were recalled and compulsory payment by check was introduced for business transactions in excess of 1,000.00 cedis. These actions eroded the public confidence in holding bank deposits and currency (Brownbridge \& Gockel, 1996).

\section{Prudential Regulation And Supervision}

The Banking Act of 1970 established the regulatory framework for the banking industry. This act imposed minimum paid-up capital requirements of 2 million cedis and 5 million cedis for foreign and locally owned banks, respectively. The minimum paid-up capital for locally owned banks later rose to 0.75 million cedis. The minimum paid-up capital for a local bank at the end of 1983 was equivalent to only $\$ 16,000$. Banks were also required to maintain capital and reserves of at least 5 percent of their total deposits. The capital adequacy requirements, however, were meaningless, because of the absence of clear accounting rules regarding the recognition of loan losses, provisioning for nonperforming assets, and the accrual of unpaid interest.

According to the World Bank report (1986), the Bank Act did provide some rules to limit imprudent behavior by banks; however, the penalties for infractions were minimal. In addition, the activities of the Bank Examination Department (BED) were largely confined only to ensure that banks complied with allocative monetary policy directives, such as sectoral credit directives, and reserve requirements, rather than prudential regulations. The BED also lacked adequate resources to monitor and inspect the banks; it had only five professional staff in the early 1980s. Among these professionals, only two had any training in bank supervision. To this effect, on-site examinations were infrequent and off-site supervision was impeded because of deficiencies in bank reporting. Due to this effect, the information necessary to evaluate the condition of the banks' asset portfolios, their profitability, and solvency were lacking (World Bank, 1986).

\section{Impact Of Pre-Reform Policies On Banking Markets}

The pre-reform policies had a great impact on the banking markets in Ghana. Financial repression caused severe financial shallowing in Ghana. The broad money/GDP ratio, which had been relatively stable and hovered around 20 percent from 1964-1974, rose briefly in the mid-1970s to a peak of 29 percent in 1976 and then collapsed to 12.5 percent in 1984 (see Table 2 below).

In 1977, the bank deposits to the GDP were recorded at 19.5 percent and fell to 7.4 percent in 1984 . A study by Aryeetey and Gockel (1990) on the informal financial sector found increases in street banking than formal sector intermediation. The main causes of the decline in financial depth, according to Aryeetey and Gockel, included the sharply negative real deposit rates that deterred savers from holding financial assets. In addition, the 1979 and 1982 currency appropriations, including the frozen customers' bank accounts and the decree which authorized the government to demand the details of customers' bank accounts, eroded public confidence in holding domestic currency and the use of the banking system. This encouraged the use of informal financial intermediaries and the holding of savings in the form of physical assets such as buildings and construction materials, or foreign assets. According to Leite (1982) banks were discouraged from active deposit mobilization because of interest rate controls and the high reserve and liquid asset requirement, which prevented banks from channeling depositors' funds into remunerative outlets. Further, the banks, at times, refused to open new time and savings deposit accounts and also refused to pay interest on accounts above a certain amount.

One of the main objectives of pre-reform financial-sector policies was to support priority sectors through the use of sectoral credit guidelines and preferential interest rates; however, the supply of credit to the priority sectors declined sharply in real terms. In 1983, credit to the nongovernmental sector which included both priority and nonpriority was recorded at 3.6 percent of the GDP compare to 9.8 percent recorded in 1977 (Aryeetey and 
Gockel, 1990). The basis for the decline in credit supply was the fall in financial depth, together with crowding out by the government's borrowing requirements that reduced the aggregate volume of funds which banks had to lend to all nongovernmental borrowers, including public enterprises. In 1983, the government took 87 percent of the net domestic credit (World Bank, 1986). According to the World Bank (1986), the sectoral credit of distribution was not realized due to the fact that the sectoral credit directives were not always effective. Credit to other priority sectors often fell short of the maximum permitted under the credit ceilings while that to nonpriority sectors often exceeded their ceilings. From the World Bank report (1986), banks were discouraged from allocating their available funds to priority sectors because of the lending rate controls which made no allowance for the risk of lending, or for transaction costs.

Table 2

Money Supply, Bank Deposits, and Credit to the Private Sector Percentages of GDP: 1970-1994

\begin{tabular}{|c|c|c|c|}
\hline Year & M2/GDP (\%) & Bank Deposits/GDP(\%) & $\begin{array}{c}\text { Bank Claims on } \\
\text { Private Sector/GDP }(\%) \\
\end{array}$ \\
\hline 1970 & 19.0 & 12.4 & 8.2 \\
\hline 1971 & 19.0 & 12.6 & 12.6 \\
\hline 1972 & 23.7 & 15.2 & 10.1 \\
\hline 1973 & 22.6 & 15.6 & 5.3 \\
\hline 1974 & 21.6 & 14.4 & 5.7 \\
\hline 1975 & 26.2 & 17.0 & 5.8 \\
\hline 1976 & 29.1 & 18.3 & 5.9 \\
\hline 1977 & 29.7 & 19.5 & 5.0 \\
\hline 1978 & 26.6 & 16.6 & 3.5 \\
\hline 1979 & 22.8 & 14.2 & 2.8 \\
\hline 1980 & 20.4 & 12.4 & 4.1 \\
\hline 1981 & 22.9 & 14.7 & 3.1 \\
\hline 1982 & 19.8 & 12.0 & 3.7 \\
\hline 1983 & 13.2 & 7.8 & 2.7 \\
\hline 1984 & 12.5 & 7.4 & 3.0 \\
\hline 1985 & 16.0 & 9.7 & 4.5 \\
\hline 1986 & 16.5 & 10.4 & 5.2 \\
\hline 1987 & 17.1 & 10.9 & 4.3 \\
\hline 1988 & 17.3 & 11.2 & 3.6 \\
\hline 1989 & 16.9 & 11.1 & 5.6 \\
\hline 1990 & 13.6 & 9.7 & 3.9 \\
\hline 1991 & 13.4 & 9.3 & 3.2 \\
\hline 1992 & 17.5 & 11.8 & 4.6 \\
\hline 1993 & 16.9 & 12.7 & 4.6 \\
\hline 1994 & 18.7 & 12.8 & 5.3 \\
\hline
\end{tabular}

Source: Adapted from Brownbridge and Gockel (1996).

Note: Money supply and bank deposit data include the deposits of the secondary banks. Claims on the private sector exclude the secondary banks prior to 1980 .

In the 1980s, the public sector banks were troubled with financial distress. The Development Finance Institutions (DFIs) ran into serious difficulties which were created first by the emergence of distress in the two main commercial banks, GCB and SSB. All the banks in the mid-1980s were rendered insolvent by nonperforming assets (NPAs) and had to be restructured in 1989-1991, when a total of 62 billion NPAs were identified in the banking system and were replaced by BOG bonds.

In 1999, most of the NPAs were transferred to the nonperforming Assets Recovery Trust (NPART). The NPAs included nonperforming loans, letters of credit, and equity investments that yielded no income. Nonperforming loans amounted to 32 billion, which represented 41 percent of all outstanding loans to the nongovernmental sector (Kapur et al., 1991). The main reason for the losses incurred by the public sector banks were that they had extended finance to nonlucrative projects to meet developmental and political pressure, 
because the government had the authority to appoint and dismiss the banks' executives and managers. The deterioration in the banks' asset portfolios was created by the economic crisis and the radical changes in economic policy that was implemented during the 1980s. Corruption and fraud also contributed to the scale of the banks' losses, with politically connected borrowers being able to access unsecured loans which would not have been given to them on commercial grounds and to avoid pressure to repay.

Despite the government's equity stakes in the foreign banks, they were able to resist most of the pressure given by the BOG to extend credit to nonlucrative borrowers. They maintained conservative lending policies with loan applications evaluated according to strict commercial criteria. To this effect, the foreign banks were able to avoid incurring substantial levels of loan losses.

\section{Post-Financial Sector Reforms}

Prior to financial liberalization, the financial sector was characterized by financial repression which, coupled with balance of payments deficits, an overvalued exchange rate, inflationary pressure, and macroeconomic disequilibrium, almost led to the collapse of the country's financial system. Negative real interest rates and budget deficits rose in 1981 to 6.5 percent as a percentage of GDP (Brownbridge and Gockel, 1996). The existing banking law did not provide sound prudential and regulatory guidelines for the banking system. Laws governing the operations of the nonbank financial institutions and some informal operators were not formalized. As was the case in Nigeria, interest rates were administratively determined and credit ceilings were imposed. No appropriate safety nets were established to safeguard against liquidity crises and no adequate regulatory and monitoring framework was put in place to prevent collusion and excessive risk-taking. With the introduction of financial sector reform in 1983, several drastic liberalization measures were taken.

The financial sector reforms in Ghana were established in the 1980s as part of the continuous Economic Recovery Program (ERP). Interest rates liberalization and the removal of the sectoral credit ceiling was part of the program (Brownbridge and Gockel, 1996). In 1989, the Financial Sector Adjustment Program (FINSAP), which was supported by the World Bank, was set up to address the institutional deficiencies of the financial system by restructuring the distressed banks, reforming prudential legislation and the supervisory system, permitting new entry into financial markets by public and private sector Financial Institutions (FIs), and developing money and capital markets. The second part of the FINSAP took place in 1994 with the goal of privatizing the public sector banks and development of nonbank financial institutions (NBFIs) to fill the gaps in the financial market not served by the banks.

The three components of the FINSAP, which most directly affects the banks, were bank restructuring, reforms of the prudential system, and the liberalization of financial markets.

\section{Restructuring The Public Sector Banks}

The 1989 restructuring of the public sector banks involved balance sheet restructuring and reforms to their management and operating procedures. The balance sheet restructuring was necessary due to the banks' insolvency. Further, the magnitude of the banks' nonprofit assets (NPAs) was too large for the banks to be able to restore adequate levels of capitalization from future profits. In the light of this, recapitalization from public funds became necessary. In 1989, the NPAs that amounted to 62 billion cedis equivalent to $\$ 170$ million or 4.4 percent of the GDP were removed from the banks' balance sheets and replaced with Bank of Ghana bonds.

In 1991, the government's specialized agency, the Non-Performing Assets Recovery Trust (NPART), was set up to take over the NPAs. By the end of 1994, the NPART had received 50.4 billion cedis of NPAs and recovered 14.1 billion cedis (World Bank, 1994). The replacement of NPAs enables most of the banks to meet the minimum capital adequacy requirement of 6 percent adjusted assets, which was prescribed in the 1989 Banking Law.

To prevent the banks from incurring losses and to reduce operating costs, it became necessary to reform their management and operating procedures. The restructuring involved the overhaul of credit policies and 
strengthening of credit appraisal, loan monitoring, and loan recovery systems, areas which had been particularly weak prior to the reforms (World Bank, 1994). Internal controls, inspections, and audits were improved, and budgetary and performance appraisal systems were introduced. Staff training programs were enhanced. To cut off costs, staffing levels were reduced by 38 percent between 1988 and 1992; some bank branches were also closed. In 1995, the government sold part of its equity stake in the Social Security Bank (SSB) to the public. The government in 1996 also sold 30 percent of its shares in Ghana Commercial Bank (GCB) to the public (Brownbridge and Gockel, 1996; Ziorklui, 2001). These measures were to safeguard banks from political interference. In this sphere, privatization became the key.

\section{Reforms To The Prudential System}

The reforms to the prudential system which entailed the revisions to the banking legislation enacted in the Banking Act of 1989 and NBFI Act in 1993 enticed the banks to introduce standard reporting and accounting procedures. The 1989 Banking Law imposed minimum paid-up capital requirements for Ghanaian- and foreignowned commercial banks of 200 million cedis and 5 billion cedis, respectively, and 1 billion cedis for development banks that provide medium- and long-term finance for trade and industry. Since the 1990s, there has been an upward revision of the capital requirements due to the high rates of inflation (Brownbridge and Gockel, 1996; World Bank, 1994).

The Banking Law established a minimum capital adequacy ratio of 6 percent of adjusted risk assets and requires banks to maintain reserve funds with transfers out of annual profits. The law also gives the BOG the authority to prescribe minimum liquid asset ratios. In accordance to the banking regulations and laws, banks cannot advance credit against the security of their own shares or directly engage in nonbanking business. However, the law does not set out limits on banks' foreign currency exposures. The banking laws have also introduced a standardized accounting system for the banks. This includes explicit criteria for the classification of loans provisioning for nonperforming assets and the nonaccrual of unpaid income (Aryeetey, 1996; Leith and Söderling, 2000; Ziorklui, 2001).

Banks are also required to submit a variety of statistical data at regular intervals to the BOG. These include data on large exposures, nonperforming loans, and connected lending. The objective of this is to facilitate off-site supervision. In the light of this, the Bank Supervision Department (BSD) of the BOG has been strengthened with staffing levels. In accordance with the Banking Law, the BOG has been given the authority to examine each bank at least once a year. In this perspective, regular on-site examinations have taken place (World Bank, 1994; Ziorklui, 2001). In 1992, the banking laws were revised, which gave the BOG increased powers in terms of banking supervision. In light of this, the BOG is now in a position to act strongly and swiftly to deal with distressed banks (Leith and Söderling, 2000). While the reforms are still likely to have considerably improved bank regulation and supervision in Ghana, how effective the prudential system has become is probably too early to evaluate.

\section{Financial Liberalization}

Ghana's financial system has been liberalized with the aim of enhancing the efficiency of resource allocation and strengthening competition. Bonaccorsi di Patti and Hardy (2005) use an econometric model to evaluate the impact of the banking system reforms in Pakistan. They suggest that financial sector reforms do not enhance financial sector efficiency, although in many instances profit performance improves more than cost efficiency. They explain that liberalization does not necessarily lead to a reduction in the dispersion of relative efficiency. Ranciere, Tornell, and Westermann (2006) also develop an integrated framework to empirically quantify and contrast the dual effects of financial liberalization. They show that financial liberalization tends to relax borrowing limitations, leading to higher investment and higher average growth. They added that financial liberalization encourages risk-taking, generates financial fragility, and increases the probability of financial crises, which often have recessionary consequences.

Accordingly, liberalization has entailed the removal of some of the allocative controls and the easing of entry restrictions into banking and has undoubtedly had significant effects on banking markets. The financial 
liberalization which has been taking place since 1987 involves the removal of interest rate control, the sectoral composition of bank lending, and the introduction of market-based instruments of money control. Several merchant banks with private sector participation have been licensed and some of the government-owned banks have been partially privatized (Leith and Söderling, 2000).

\section{Liberalization On Interest Rates And Credit Directives}

The maximum lending rates and the minimum time deposit rates were removed in 1987, due to interest rate liberalization. In 1990, the minimum savings deposit rates were also eliminated. In 1992, the bank-specific credit ceilings that had been the main instrument of monetary control, which was employed during the ERP, were also removed. This was replaced with an indirect market-based system of monetary control that involved the weekly auction of Treasury Bills and other government and BOG securities which were backed up with statutory cash reserves and liquid asset requirements (Alexander et al., 1995). Hence, by the early 1990s, banks were free to price deposits and to allocate loans according to market criteria. However, the major constraint on the volume of credit that banks were able to extend was the high reserve ratio that was imposed by the BOG.

\section{Credit Allocation}

Liberalization of controls over interest rates and credit can improve the efficiency of credit allocation. This can enable banks to direct credit toward those borrowers capable of generating the highest rate of return. The main constraint to an increase in the efficiency of credit allocation by the banks has been macroeconomic instability, as in several other African countries undertaking financial sector reforms. Bank lending has also been constrained by the high ratios imposed by the BOG, in an attempt to restrain monetary growth. Bank lending to the private sector has remained at very low levels since the financial sector reforms began. In 1994, bank lending was only 5.3 percent of GDP (Brownbridge and Gockel, 1996).

\section{Development Of Money And Capital Markets}

The capital and money markets in Ghana are not well developed, which has undermined the development of the financial system and has paved the way for the banks to dominate the financial system. It is believed that active development and creation of the capital and money markets give many opportunities for both savers and investors to diversify, which provides avenues for active liquidity management by financial institutions and monetary control by the central bank. However, the process of developing these markets has been loaded with many predicaments. To this effect, assistance was sought from international financial institutions under the reform program to establish a stock exchange market and discount house. As a result, two discount houses were instituted between 1987-1991 and a stock exchange market in 1989.

The Ghana Stock Exchange (GSE) began full operations at the end of 1990 with 12 listed companies and one government bond. Market capitalization within the first two years of operation increased from 30 billion cedis in 1991 to 43 billion cedis in 1992, while the listed companies increased to 15. In 1993, the total market capitalization went up by approximately 120 percent to 95 billion cedis. Thus, the GES operated as a profitable investment venture for the Ghanaian economy, with total capital gains amounting to 123 percent at the end of 1993. The market was able to raise about 140 billion cedis and US $\$ 4.8$ million through its equities and bonds, during the first seven years of operations. The number of listed companies also rose to 21 within these periods.

\section{Impact Of Changes}

The financial sector reforms have provided the necessary platform for the banking sector to operate on the basis of operational flexibility and functional autonomy, thereby enhancing efficiency, productivity, and profitability. Since the restructuring exercise began, the performance of the public sector banks has been reasonably healthy. The bank rates of return to capital between 1991 and 1995 exceeded inflation. This has allowed the banks to build enough capital and reserve. To this effect, it has enabled the banks to meet the minimum capital adequacy ratios that were imposed by the 1989 Banking Law. The banks have also been 
generally liquid. However, they are still afflicted by significant levels of NPAs, albeit not at the levels that prevailed prior to the restructuring, although the loans in the banks' asset portfolios have been low.

The banks have also done little lending since the restructuring exercise began. Most of the banks' assets have been held as liquid assets, primarily in government and BOG securities, which, since the introduction of the Treasury Bills' auction, have provided a remunerative and safe source of income. Between 1991 and 1995, the five public sector banks' average ratio of loans to total assets was only 22 percent. This low level of lending was partly attributed to the high liquid assets ratios that were imposed by the BOG (Bank of Ghana, 2004). While the restructuring has enabled the banks to stop making bad loans, it is not yet clear that it has enabled them to make good loans.

The banking system has been relatively easy to supervise during the 1990s, for two reasons. First, the scope for reckless banking behavior has been limited. This is due to the very high reserve requirements and the availability of high-yielding government and Bank of Ghana securities. In light of this, the banks have adopted conservative asset management with lending and other risk assets, which formed a small share of their total portfolios. The reform has also brought about structural changes in the financial sector and succeeded in easing external constraints on its operation, introducing transparency in reporting procedures, restructuring and recapitalizing banks, and enhancing the competitive element in the market through the entry of new banks (Bank of Ghana, 2004).

There have been several new entrants into the banking markets since the reforms began. In 1990, Continental Acceptance (CAL) and Ecobank began their operations with a joint venture, which involved both local public sector shareholders and foreign shareholders. In 1992, Meridian Bank BIAO, a foreign commercial bank, was established with minority local shareholding by the Social Security and National Insurance Trust (SSNIT). First Atlantic and Metropolitan and Allied Merchant banks started operations in 1995. During the 1990s, about 20 NBFIs, including leasing companies, finance houses, building societies, and savings and loan companies, have been established. This is an addition to the new entry into the banking markets. Many of these NBFIs accept deposits and extend credit and, therefore, have some competition for the services offered by the banks.

New entry has brought about a small reduction in market concentration in the banking industry. The share of the largest four banks in total bank deposits fell from 76 percent in 1988 to 70 percent in 1994. The industry, however, remains highly oligopolistic. According to Aryeetey (2005), if competition has increased, it appears to have been mainly limited to the segments of the deposit and credit markets that involve corporate and institutional customers. Most of the new entrants have been in merchant banking rather than retail banking, and the established commercial banks have reduced their retail branch networks.

Liberalization has not yet had a major impact on innovation in banking markets or the quality of services offered to the public. There has been very little innovation in terms of the range of instruments and services provided. Only very basic savings and lending instruments are available from the banks. Interest-bearing checking accounts are generally only available to customers with very large deposits (World Bank, 1994).

The failure of financial liberalization to stimulate greater improvements in the range and quality of retail banking services requires some explanation. It may be attributable to the lack of competitive pressure on the banks which have been able to generate profits during the 1990s, mainly from investing in securities, without having to compete vigorously for either deposits or borrowers. It is also possible that the very low usage of the banking system by the public makes the introduction of innovative retail services uneconomical. In turn, the public is deterred from using the banks, partly because services are poor, but also because holding bank deposits is unattractive given the high rates of inflation. It is likely that a combination of sustained low inflation and greater competition will be needed if retail services are to improve. The ongoing revolution in information and communication technology has improved. However, given the low initial level of automation, it has largely bypassed Ghana's banking system (Bank of Ghana, 2004). 


\section{Structure Of Ghana's Banking System}

This section of the paper presents a brief overview of Ghana's banking structure.

The Ghanaian banking system is characterized by a mixed ownership structure and by the differences in customer base. At the end of 2003, 18 banks were operating in Ghana. This increased to 21 by the end of 2005. The rural and community banks also increased to 121 (Bank of Ghana, Annual Report, 2005). The banking system in Ghana is made up of 7 commercial banks, 8 universal banks, 2 merchant banks, 3 development banks, and 121 rural and community banks (Bank of Ghana, 2005; Buchs \& Mathiesen 2005). Table 3 provides a picture of the structure of Ghana's banking system.

Table 3

Structure of the Banking Sector

\begin{tabular}{|c|c|c|c|c|c|c|c|c|}
\hline & \multicolumn{3}{|c|}{ Ownership (Percent) } & \multirow[b]{2}{*}{$\begin{array}{l}\text { As percent } \\
\text { of GDP }\end{array}$} & \multicolumn{4}{|c|}{ Share of Total (Percent) } \\
\hline & Ghanaian & Foreign & $\begin{array}{c}\text { Total } \\
\text { Assets } \\
\text { (Bns of cedis) }\end{array}$ & & $\begin{array}{c}\text { Number } \\
\text { of Branches }\end{array}$ & $\begin{array}{c}\text { Total } \\
\text { Assets }\end{array}$ & $\begin{array}{c}\text { Net } \\
\text { Lending }\end{array}$ & Deposits \\
\hline Banking System & & & 18,668 & 38.2 & 309 & 100.0 & 100.0 & 100.0 \\
\hline Commercial Banks & & & 13,055 & 26.7 & 229 & 69.3 & & \\
\hline Bank 1 & 97 & 3 & 4,624 & 9.46 & 134 & 24.8 & 16.9 & 20.8 \\
\hline Bank 2 & 10 & 90 & 2,710 & 5.55 & 24 & 14.5 & 18.1 & 16.0 \\
\hline Bank 3 & 24 & 76 & 3,011 & 6.16 & 23 & 16.1 & 16.3 & 18.8 \\
\hline Bank 4 & 46 & 54 & 1,713 & 3.50 & 38 & 9.2 & 16.2 & 8.8 \\
\hline Bank 5 & 39 & 61 & 470 & 0.96 & 6 & 2.5 & 2.1 & 2.6 \\
\hline Bank 6 & 53 & 47 & 128 & 0.26 & 4 & 0.7 & 0.6 & 1.0 \\
\hline Bank 7 & 0 & 100 & 120 & 0.25 & 3 & 0.6 & 0.3 & 0.8 \\
\hline Bank 8 & 9 & 91 & 230 & 0.47 & 1 & 1.2 & 0.5 & 1.2 \\
\hline Bank 9 & 100 & 0 & 49 & 0.10 & 1 & 0.3 & 0.3 & 0.3 \\
\hline Merchant Banks & & & 2,875 & 5.9 & 18 & & & \\
\hline Bank 10 & 100 & 0 & 751 & 1.54 & 5 & 4.0 & 4.8 & 5.4 \\
\hline Bank 11 & 6 & 94 & 1,325 & 2.71 & 4 & 7.1 & 8.2 & 5.4 \\
\hline Bank 12 & 34 & 66 & 409 & 0.84 & 3 & 2.5 & 2.1 & 2.6 \\
\hline Bank 13 & 71 & 29 & 286 & 0.59 & 2 & 1.5 & 1.5 & 2.0 \\
\hline Bank 14 & 100 & 0 & 104 & 0.21 & 1 & 0.6 & 0.4 & 0.7 \\
\hline Development Banks & & & 2,738 & 5.6 & 62 & & & \\
\hline Bank 15 & 100 & 0 & 1,847 & 3.78 & 42 & 0.0 & 11.2 & 8.4 \\
\hline Bank 16 & 100 & 0 & 538 & 1.10 & 14 & 0.0 & 3.8 & 2.0 \\
\hline Bank 17 & 100 & 0 & 352 & 0.72 & 6 & 0.0 & 1.9 & 2.0 \\
\hline
\end{tabular}

Source: Buchs and Mathisen, 2005.

Commercial banks engage in traditional banking business, with a focus on universal retail services. Merchant banks are fee-based banking institutions and mostly engage in corporate banking services. Development banks specialize in the provision of medium- and long-term finance (Buchs \& Mathisen, 2005). According to the Bank of Ghana annual report (2005), the four largest commercial banks control 51.2 percent of the total assets of the banking sector and hold about 55.8 percent of the total deposits. The nine smaller commercial banks own about 14.2 percent of the total assets and 13.3 percent of the total deposits. The nine smaller commercial banks operate on a much smaller scale. The universal banks and merchant banks control approximately 18.6 percent and development banks share about 15.8 percent of the total asset base of the banking sector.

Ghana Commercial Bank (GCB) alone holds about 25 percent of the total assets and 20 percent of the deposits. Foreign investors hold about 53 percent of shares in eight commercial banks and three banks are state owned. The banking penetration ratio at one bank branch per 54,000 inhabitants is relatively high, but formal banking reaches only 5 percent of the population, and the coverage varies widely. This reflects the fact that 35 percent of bank branches are in the greater Accra region, even though this region represents less than 13 percent of the country's population. About half of all bank branches in the interior belong to the dominant state-owned 
bank. There are also several rural banks and a stock exchange. However, most of these institutions are underdeveloped, inefficient, and reach only a low share of the population (IMF, 2003b). Rural banks, which were designed to overcome this problem, tend to focus on mobilizing rural savings, but are often reluctant to provide credit in rural areas (IMF, 2003a).

\section{Banking Sector Performance}

In this section, an attempt is made to use some of the profitability index to describe the performance of Ghana's banking system. Ghana banks have over the years posted high levels of profits in spite of the unstable economic atmosphere that has caused the collapse of other businesses. Factors that have contributed to the high profit include high bank transaction fees and high net interest income.

Table 4

Financial Soundness Indicators for the Banking Sector, 1997-2003 (in percent at year's end, unless otherwise indicated)

\begin{tabular}{|c|c|c|c|c|c|c|c|}
\hline & 1997 & 1998 & 1999 & 2000 & 2001 & 2002 & 2003 \\
\hline \multicolumn{8}{|l|}{ Capital Adequacy } \\
\hline Regulatory capital to risk-weighted assets $1 /$ & 15.2 & 11.1 & 11.5 & 11.6 & 14.7 & 13.4 & 9.3 \\
\hline Percentage of banks greater or equal to 10 percent & 87.5 & 75.0 & 60.0 & 62.5 & 64.7 & 52.9 & 66.7 \\
\hline Percentage of banks below 10 and above 6 percent minimum & 6.3 & 12.5 & 40.0 & 37.5 & 35.3 & 35.3 & 27.8 \\
\hline Percentage of banks below 6 percent minimum & 6.3 & 12.5 & 0.0 & 0.0 & 0.0 & 11.8 & 5.6 \\
\hline Capital (net worth) to assets & 13.4 & 12.2 & 12.2 & 11.9 & 13.1 & 12.6 & 12.5 \\
\hline \multicolumn{8}{|l|}{ Asset Quality } \\
\hline Foreign exchange loans to total loans 5/ & 25.6 & 28.5 & 33.4 & 35.3 & 34.1 & 33.8 & $\ldots$ \\
\hline Past-due loans to gross loans & 24.6 & 18.9 & 20.1 & 16.2 & 28.0 & 28.6 & 24.4 \\
\hline Nonperforming loans & 21.6 & 17.2 & 12.8 & 11.9 & 19.6 & 19.6 & 22.7 \\
\hline Watch-listed loans & 3.0 & 1.7 & 7.3 & 4.3 & 8.4 & 5.9 & 6.0 \\
\hline Provision as percent of past due loans & 78.0 & 89.4 & 67.2 & 58.6 & 46.4 & 63.6 & 64.4 \\
\hline \multicolumn{8}{|l|}{ Earnings and Profitability } \\
\hline Net profit (before tax)/net income & 51.5 & 39.2 & 61.2 & 52.4 & 45.9 & 43.4 & 39.2 \\
\hline Return on assets $2 /$ & 8.0 & 8.6 & 8.5 & 9.7 & 8.7 & 6.8 & 6.4 \\
\hline Return on equity $3 /$ & 39.9 & 48.9 & 48.8 & 65.7 & 49.7 & 36.9 & 54.0 \\
\hline Expense/income & 44.0 & 42.2 & 44.3 & 38.2 & 40.2 & 47.3 & 36.0 \\
\hline \multicolumn{8}{|l|}{ Interest Rate Spread (deposit money banks) } \\
\hline Lending rates minus demand deposit rates & 37.0 & 33.8 & 32.5 & 30.5 & 30.5 & 30.5 & 23.3 \\
\hline Lending rates minus demand saving rates & 16.3 & 22.0 & 23.5 & 29.3 & 29.5 & 29.5 & 23.0 \\
\hline \multicolumn{8}{|l|}{ Liquidity } \\
\hline Actual reserve ratio (as percent of total deposits) & 60.1 & 64.8 & 61.8 & 49.9 & 62.9 & 66.0 & 66.1 \\
\hline Excess reserve ratio 4/ & 17.1 & 21.8 & 18.8 & 5.9 & 18.4 & 22.0 & 22.1 \\
\hline Loan/deposit & 42.2 & 48.7 & 59.0 & 64.0 & 63.9 & 50.1 & 56.1 \\
\hline Foreign exchange liabilities/total liabilities 5/ & 24.9 & 21.1 & 29.7 & 36.2 & 27.0 & 27.4 & $\ldots$ \\
\hline \multicolumn{8}{|l|}{ Sensitivity to market risk } \\
\hline $\begin{array}{l}\text { Net foreign exchange assets } \\
\text { (Liabilities) to shareholders' funds } 5 /\end{array}$ & 62.9 & 48.1 & (7.6) & $(9.4)$ & 22.9 & 24.3 & \\
\hline
\end{tabular}

Source: Buchs and Mathiesen, 2005.

The key financial performance indicators show mixed results. The average capital adequacy ratio (CAR) that was recorded in the year 2002 was about 13.4 percent and 9.27 percent in 2003 . This was well over the minimum 6 percent required by law (Bank of Ghana, 2004; Buchs \& Mathiesen, 2005). There was a wide dispersion among banks. In the light of this, two small commercial banks were not able to meet the minimum capital standard requirement. This prompted the intervention by bank supervisors. Further, the asset quality of the banks' loan portfolio had been negatively impacted, due to the adverse macroeconomic developments in 1999 and 
2000. The nonperforming loans and past-due loans increased from 16.2 percent in 2000 to as high as 28.6 percent in 2002 and slightly decreased to 24.4 percent in 2003 (see Table 4).

The overall impact of the worsening asset quality of the banks' loan portfolio on the banking system has lessened by the relatively prudent lending of the two largest foreign-owned banks (Bank of Ghana, 2004; Buchs and Mathiesen, 2005).

Table 5

International Comparison of Selected Banking and Institutional Indicators (in percent, unless otherwise indicated)

\begin{tabular}{|c|c|c|c|c|c|c|c|c|c|}
\hline & Ghana & Kenya & Mozambique & Nigeria & $\begin{array}{l}\text { South } \\
\text { Africa }\end{array}$ & Tanzania & Uganda & Zambia & $\begin{array}{c}\text { SSA } \\
\text { Average }\end{array}$ \\
\hline \multicolumn{10}{|l|}{$\begin{array}{l}\text { Size of financial } \\
\text { intermediaries }\end{array}$} \\
\hline $\begin{array}{l}\text { Private credit to } \\
\text { GDP }\end{array}$ & 11.8 & 26.8 & 16.7 & 14.4 & 147.2 & 4.9 & 40. & 7.5 & 15.2 \\
\hline M2 to GDP & 19.0 & 43.8 & 5.1 & 25.8 & 87.2 & 18.3 & 13.0 & 16.9 & 24.8 \\
\hline $\begin{array}{l}\text { Currency to } \\
\text { GDP }\end{array}$ & 10.5 & 13.2 & 15.6 & 10.8 & 28.4 & 8.5 & 8.8 & 6.4 & 13.9 \\
\hline \multicolumn{10}{|l|}{ Banking industry } \\
\hline Number of banks & 17 & 53 & 10 & 51 & 60 & 29 & 15 & 16 & .. \\
\hline $\begin{array}{l}\text { Net interest } \\
\text { margin }\end{array}$ & 11.5 & 5.0 & 5.9 & 3.8 & 5.0 & 6.5 & 11.6 & 11.4 & 8.3 \\
\hline Overhead costs & 7.3 & 3.7 & 4.5 & 7.4 & 3.7 & 6.7 & 4.6 & 11.2 & 5.7 \\
\hline $\begin{array}{l}\text { Foreign bank } \\
\text { share (assets) }\end{array}$ & 53 & 4.8 & 98 & 11.0 & 0.6 & 58.7 & 89.0 & 66.6 & .. \\
\hline $\begin{array}{l}\text { Bank } \\
\text { concentration ( } 3 \\
\text { banks) }\end{array}$ & 55.0 & 61.6 & 76.6 & 86.5 & 77 & 45.8 & 70.0 & 81.9 & 81.0 \\
\hline $\begin{array}{l}\text { Nonperforming } \\
\text { loans (share of } \\
\text { total loans) }\end{array}$ & 28.8 & 41.0 & $\ldots$ & 17.3 & 3.9 & 12.2 & 6.5 & 21.8 & .. \\
\hline \multicolumn{10}{|l|}{ Capital markets } \\
\hline \multicolumn{10}{|l|}{$\begin{array}{l}\text { Stock market } \\
\text { capitalization }\end{array}$} \\
\hline $\begin{array}{l}\text { (Percent of } \\
\text { GDP) }\end{array}$ & 10.1 & 9.2 & $\ldots$ & 10.9 & 77.4 & 4.3 & 0.6 & 6.0 & 21.3 \\
\hline \multicolumn{10}{|l|}{$\begin{array}{l}\text { Contract } \\
\text { enforcement }\end{array}$} \\
\hline $\begin{array}{l}\text { Number of } \\
\text { procedures }\end{array}$ & 21 & 25 & 18 & 23 & 16 & 26 & 14 & 1 & 29 \\
\hline $\begin{array}{l}\text { Duration } \\
\text { (number of days) }\end{array}$ & 90 & 255 & 540 & 730 & 99 & 207 & 127 & 188 & 334 \\
\hline \multicolumn{10}{|l|}{ Bankruptcy } \\
\hline Time in years & $\ldots$ & 4.6 & $\ldots$ & 1.6 & 2.0 & 3.0 & 2.0 & 3.7 & 3.5 \\
\hline \multicolumn{10}{|l|}{ Credit markets } \\
\hline $\begin{array}{l}\text { Credit rights } \\
\text { index ( } 0 \text { is } \\
\text { weakest })^{1}\end{array}$ & 1 & 1 & 3 & 1 & 2 & 3 & 1 & 2 & 2 \\
\hline \multicolumn{10}{|l|}{ Entry regulations } \\
\hline $\begin{array}{l}\text { Number of } \\
\text { procedures }\end{array}$ & 10 & 11 & 16 & 9 & 9 & 13 & 17 & 6 & 11 \\
\hline $\begin{array}{l}\text { Duration } \\
\text { (number of days) }\end{array}$ & 84 & 61 & 153 & 44 & 38 & 35 & 36 & 40 & 72 \\
\hline $\begin{array}{l}\text { Cost (percent } \\
\text { of GNI per } \\
\text { capita) }\end{array}$ & 111 & 54 & 100 & 92 & 135 & 9 & 199 & 24 & 255 \\
\hline
\end{tabular}

Source: Buchs and Mathisen, 2005. 
The banking system is also characterized by high overhead costs. The five largest banks incur, on average, overhead costs of 7 percent of total assets, which is similar to the sector as a whole but significantly higher than the Sub-Saharan African average of 5.7 percent. It can be noted that these costs are, however, lower than those reported in Nigeria and Zambia (see Table 5).

One key element that explains the high total overhead cost is the staff-related expenditure component which accounted for more than half of the total overhead costs (about 3.7 percent to average assets). The dominant state-owned bank (Bank 1), for example, has one of the highest staff costs which accounts for 4.3 percent of average assets, while the large commercial bank's average is 3 percent. The high staff costs to total assets ratio has undermined the low levels of assets per employee and the relatively high average staff cost per employee. The high cost can also be explained by the huge investments in the banking infrastructure, notably in information and communication technologies as telecommunication in particular suffers from interconnectivity problems. Another factor associated with the high cost is reflected in some marketing activities such as the repudiation to network, the automated teller machines, which appear to have led to unduly high investments in such systems (Buchs and Mathiesen, 2005).

Despite the high overhead costs and sizable provisioning, profitability indicators show that Ghanaian banks' pretax returns on assets and equity are among the highest in Sub-Saharan Africa (see Table 6). This situation reflects very wide interest margins. The return on asset (ROA) was recorded at 6.1 percent and 6.4 in 2002, while return on equity (ROE) stood at 35.56. This is remarkable by African standards. Net interest revenue and noninterest revenue also stood at 10 percent and 6.4 percent of average assets. The decline in interest rates in 2002 reduced the banks' income from government securities and led to a slight narrowing of interest-rate spreads, but the latter remains between 20 and 30 percent. Net interest revenue and noninterest revenue as a percentage of gross income in 2003 were recorded at 63.18 percent and 36.83 percent, respectively. The high cost of intermediation is due to the combination of wide interest margins, sizable overhead costs, and an ample supply of relatively low-risk, high-return, and government paper. For the stability of the banking system, the poor quality of banks' loan portfolios has become a major source of concern, since the large interest margins are reflected in the nonperforming loan problem (Bank of Ghana, 2004; Buchs and Mathiesen, 2005).

The development in the banking system has shown a strong asset growth and improved profitability. This has strengthened the banks' capital position to absorb adverse shocks (Bank of Ghana, 2007). Total assets of the banking industry at the quarter of 2007 was recorded at GHф5.62 billion (Ghana's new currency). This is an annual growth of 41.6 percent as compared with 24.0 percent in March 2006 (GH $\phi 3.97$ billion). The significant growth of the total assets was due to the growth in advances. Net loans and advances reached GH $\phi 2.63$ billion at the end of March 2007. This is a record of 58.1 percent annual growth compared to 41.8 percent in March 2006. The growth in the banking industry size was significantly funded primarily by deposits which are recorded at GH $\notin 3.68$ billion. This is an annual growth of 41.9 percent in March 2007, compared with 26.3 percent annual growth in March 2006. The significance of bank loans in the overall economy has also increased. This is evidence by the increase in the ratio of gross advances of GDP to 24.6 percent as of March 2007, compared with 16.3 percent recorded in March 2006. Deposit growth has been significantly high. At the end of March 2007, deposits reached GH $₫ 3.68$ billion compared with $\mathrm{GH} \phi 2.59$ billion in 2006. This shows an annual growth of 41.9 percent (Bank of Ghana, 2007).

This development is encouraging; however, it may also reflect the low level of diversification of the Ghanaian financial system. The role of deposits as a source of bank funding remains significantly high. The ratio of total deposits in GDP increased to 32 percent in March 2007, as compared with 22.6 percent in March 2006. The significant decline in the ratio of nonperforming loans (NPL) in total loan portfolio is due to the stable macroeconomic environment which is favorable to borrowers. At the end of March 2007, the NPL ratio remains at 6.9 percent, compared with the 12.9 percent that was recorded during the same period in 2006 . At the same token, the bank's loan loss provisions to gross declined from 11.13 percent in March 2006 to 6.8 percent in March 2007. The NPL net of provisions to capital also declined significantly from 7.0 percent in March 2006 to 0.61 percent in March 2007. The achievement in the development of the banking industry's lending activity is significantly due to the stability of the macroeconomic environment (Bank of Ghana, 2007). 
The liquidity ratio of the banking sector remains satisfactory. The liquid asset ratio (core) declined from 20.9 percent in February 2007 to 19.5 percent in March 2007. The broad measure similarly declined from 46.0 percent in February 2007 to 43.8 percent in March 2007. Short-term interbank liabilities in total liabilities dipped further from 2.8 percent in February 2007 to 2.2 percent in March 2007. Credit to deposit and borrowing ratio on the other hand inched up from 58.5 percent in February 2007 to 60.4 percent in March 2007. Liquidity levels in general may be considered as stable and safe.

The solvency of the banking industry, as measured by the Capital Adequacy Ratio (CAR), continues to be high, remaining well above the statutory threshold of 10.0 percent. The industry CAR inched up to 16.9 percent as of March 2007 from 16.6 percent in February 2007. The industry CAR stood at 16 percent in March 2006 (Bank of Ghana, 2007).

There has been a substantial improvement in the industry profitability. The banks' operating income reached $\mathrm{GH} \phi 1,752$ billion in the quarter of 2007 compared to $\mathrm{GH} \not 1,333.3$ billion recorded in 2006. This represents an annual growth of 31.5 percent compared with 7.9 percent in March 2006. This development is due to improvement in net interest income which was recorded at $\mathrm{GH} \phi 1,165.6$ up from $\mathrm{GH} \not 889.5$ billion. This shows an annual growth of 31.0 percent compared to 7.8 percent in 2006 . The considerable decline in the default rate may be due to an increase in the banks' loan portfolio and the improvement in the macroeconomic environment.

The structure of the banks' income continues to be stable with interest income accounting for 74.1 percent of the banks' total income compared with 25.9 percent for noninterest income in March 2006 for interest income and noninterest income, respectively. Income from fees and commissions declined by 19.7 percent as of March 2007, compared with 21 percent as recorded in the first quarter of 2006. Similarly, the share of noninterest income declined from 77 percent in March 2006 to 76.1 percent in March 2007 (Bank of Ghana, 2007).

The share of investment income (bills, securities, and shares) in total income continues to decline, possibly reflecting the decline in the banks' investment in these instruments as a result of their unfavorable returns. The share of income from loans and advances continues to surge. This may be due to the significant rise in the loan portfolio coupled with a favorable macroeconomic environment, resulting in improved ability to service loans. Banks' operating expenses increased by 35.1 percent in March 2007 compared with 11.7 percent in March 2006. The growth was driven by the significant growth in administrative expenses and staff cost which recorded an annual growth of 28.8 percent and 18.7 percent, respectively, in March 2007.

Net operating income reached GH $\phi 740.5$ billion in March 2007 up from the GH $\phi 584.2$ billion recorded during the same period in 2006, registering an annual growth of 26.7 percent compared with a deceleration of 24.8 percent in March 2006. Reduction in total provisions (bad debts and depreciation), which decelerated by 2.7 percent, coupled with slower growth in taxes, resulted in net income of GH $\$ 427.2$ billion up from the GH $\notin 289.2$ billion recorded in March 2006. This translates into an annual growth of 47.7 percent in March 2006. There is also a significant increase in the banking industry's return on equity (ROE) which reached 27.3 percent in March 2007 compared with 24.3 percent in March 2006. The total return on assets (ROA), however, declined marginally to 4.23 percent in March 2007 from 4.27 percent in March 2006. This development has resulted from the relatively stronger growth in aggregate assets compared with the growth in aggregate net profits.

The efficiency of the banking industry has relatively improved. The marginal improvements in the costasset and cost-income ratios reflect the sustained growth in asset and income rather than improved cost levels, whose growth has remained relatively, stable (Bank of Ghana, 2007).

The financial deepening over the years in Ghana has been limited by certain factors, which explains the trend of both the profitability and efficiency indicators of the banking system. The development of the financial sector is associated with healthy macroeconomic policies. In light of this, macroeconomic stability is vital to such a development. This is important because Ghana's macroeconomic policies over the last decade have been characterized by periodic financial discipline slippages. This has led to volatile and generally high inflation, large exchange rate swings, and negative real interest rates over the years (Bank of Ghana, 2004). An example of macroeconomic imbalances includes the severe terms of trade shock that occurred between 1999 and 2000. This, 
combined with fiscal slippages, resulted in inflationary pressures, 15 percent exchange-rate depreciation, and the buildup of a sizable domestic government debt.

It is instinctive to presume that the high degree of uncertainty related to Ghana's unbalanced macroeconomic environment has negatively affected both the size and the quality of financial intermediation. This assumption is evidenced by the low level of overall savings and investment. Between 1996 and 2002, the savingsto-GDP ratio was recorded at 15.9 percent, while the private investment ratio was 10.6 percent (Buchs \& Mathiesen, 2005).

On average, Ghana compared poorly to other African countries. The low bank intermediations seem to coexist with a wide range of savings ratios. Another piece of substantiation is the short time horizon in the overall financial sector. Long-term savings are practically nonexistent, as one-third of all deposits are demand deposits, and terms for bank loans hardly extend beyond one year.

Another factor that explains the bank profitability and efficiency of intermediation in Ghana is the risky lending environments that exist there. This is evidenced by the high levels of nonperforming loans (NPLs) posted by the banking system over the years. The NPLs, as a percentage of total loans, rose from an average of 10.62 percent at the end of the year 2000 to 18.72 percent at the close of the first quarter of 2004 (Bank of Ghana, 2004). The NPLs in Ghana's banking system are largely due to the significant losses of some state-owned companies. Also the lack of any central credit information system and the lack of cooperation among banks in sharing customer information contributed to the high degree of NPLs (Buchs \& Mathisen, 2005). Some institutional factors may also affect the environment in which financial institutions operate. As shown in Table 5, the enforcement of creditors' rights in Ghana is weak as compared with the Sub-Saharan African average. The increasing rate of bad and doubtful debt, which has become a source of worry for the financial sector, has led to the making of huge provisions by the banks for extended periods (Bank of Ghana, 2004; Buchs \& Mathisen, 2005).

Another factor that has contributed to the low and inefficient intermediation in Ghana is the uncompetitive structure of the financial market. According to the Bank of Ghana (2004), the oligopolistic or monopolistic behavioral tendencies have resulted in higher intermediation costs and diseconomies of management than under the competitive structure. This is evidenced by the presence of wide interest-rate margins and spreads that tend to discourage prospective depositors and possible borrowers. The upshot is the low lending ratios. The high cost could be partly explained by recent high investments in banking infrastructure, especially in telecommunication, which still suffers from interconnectivity problems.

The banks have also identified some structural and policy issues as contributing to the high overhead cost of banking in Ghana. The key among them is the Bank of Ghana reserve requirements, especially the noninterest earnings on primary reserves. A review of the banks' operations by the BOG in 2003 suggested that the banks in Ghana are not handicapped by the BOG current reserve requirement structure. The review indicated that banks carried excess reserve including the primary reserve of about 40 percent of total deposit liabilities for most of 2003. The reserve requirement structure within the West African subregion suggested that the 9 percent primary reserve (non-interest-bearing) required of banks that operate in Ghana is quite moderate. In Gambia, banks are required to hold 14 percent of total deposit liabilities with the Central Bank as a primary reserve. The primary reserve requirement in Nigeria and Guinea are 12.5 percent and 5.5 percent, respectively. Ghana's primary reserve is therefore the second lowest among the four West African countries. The banks also contended that the National Reconstruction Levy calculated on banks' and other companies' pre-tax earnings constitute a tax on their earnings. The National Reconstruction Levy Act, 2001 (Act 597), imposed a special levy of 10 percent and 7.5 percent on the profits (before tax) of banks and nonbank financial institutions, respectively. For all other companies, a levy of 2.5 percent was imposed on their profits. The 10 percent special levy imposed on banks' operating profits is admittedly high and underlies the increase in the high operational costs and high intermediation service charges of banks (Bank of Ghana, 2004). 


\section{Policy Discussion}

Banks operating in Ghana have over the years recorded high levels of profits notwithstanding the harsh economic environment that has led to the collapse of other businesses. High bank transaction fees and tariffs as well as high net interest income contributed significantly to these high profits.

The National Reconstruction Levy calculated that banks' pre-tax earnings constitute a tax on their earnings, which are passed on to bank customers. Contrary to the views expressed by some banks, a comparative analysis or reserve requirement structures revealed that banking operations in Ghana are not unreasonably constrained. The uncertainty associated with Ghana's unstable macroeconomic environment, the risky lending environment, and the structure of the banking sector all have prevented further financial deepening in Ghana over the years.

It is hoped that the Bank of Ghana would, in concert with the fiscal authorities, continue to work toward consolidating and entrenching macroeconomic stability, so that inflation and interest rates continue their downward trend while maintaining exchange-rate stability. This should hopefully remove distortions in the economy and allow a smooth development of the financial markets through the adoption of new technologies, accompanied by efficiency gains and quality services. To deliver these efficiency gains and quality services, banks must adopt high professional standards, hire and train qualified staff and management teams, and computerize their operations. The banks would then be in the position not only to pay prompt attention to customers' needs, but also to shorten the time it takes to transact business at the banks and thereby reduce the public's banking transaction costs. This is the challenge for both the banks and the central bank as the regulator in their quest, to deepen financial intermediation and evolve into an efficient banking system.

\section{EVALUATION OF REFORMS}

The reforms of the last decade have been successful along the dimension of improvement in the banking sector. In many respects, the outcome of the reform in Ghana reflected the pace of its implementation. The nominal deposit and lending rates increased gradually from 1984 together with the scope of liberalization. After five years, the average nominal lending rate increased by just 3.7 percent over its level at the start of the program (Emengu, 2000). Immediately when the reform started, the interest rate spread dropped considerably but later rose above the pre-reform levels. The higher default risk and its associated cost within the reform period was a major cause of the increasing interest rate spread (Aryeetey and Seini, 1992).

Improvement in the real deposit rate has been very significant. In the first year of the reforms (stabilization with interest-rate liberalization), real deposit rates increased by 86.7 percentage points (from $111.5 \%$ to $+24.8 \%$ ). Further into the reforms, positive real deposit rates were achieved. Between the pre-reform and the reform periods, the real deposit rate increased by 52.2 percent, although it remained negative (Emengu, 2000). This resulted mainly from the stabilization measures that led to lower rates of inflation. The contribution of nominal interest rate growth was marginal. The period of adjustment witnessed increased macroeconomic stability. The deficit/GDP ratio dropped drastically from 5.1 percent average to 0.1 percent. The rate of inflation declined by 47.0 percentage points from 73.3 percent to 26.3 percent, on average. In 1983, the rate of inflation was as high as 123 percent, whereas since the full implementation of the reform, the highest rate has been 39.8 percent. In some years, it was as low as 10 percent. An impressive growth in real GDP has also been achieved. For the four consecutive years preceding the reform, real GDP growth was negative. But since the adjustment program, the real GDP growth has ranged from 3.0 percent to 5.6 percent (Emengu, 2000).

The Ghanaian financial system has been profoundly transformed since the joint IMF-World Bank Financial Sector Assessment Program (FSAP) assessment in 2000 and its update in 2003. The FSAP identified key elements of a medium-term, financial-sector strategy reflecting the government's priorities. Some indicators of Ghana's success are the following:

- Ghana's financial sector development has had a notable impact on growth, which rose to 6.3 percent in 2007 from 4.5 percent in 2002 prior to the onset of reforms. 
- $\quad$ The ratio of money (M2) to GDP, the traditional measure of financial deepening, doubled after 2004, reaching 43 percent of GDP by the end of 2007. Much of the increase was funded by an increase in demand and savings deposits.

- $\quad$ The banking system has grown rapidly, fueled by fast credit expansion. Banks now account for about 70 percent of the financial sector.

- $\quad$ Financial sector vulnerabilities have been reduced. Improved banking supervision now gives priority to capital adequacy, bank risk management, and more on-site supervision.

- $\quad$ The government has passed most of the bills recommended by the 2003 FSAP to improve both prudential supervision and the legal basis for financial intermediation.

Although the Ghanaian financial system incorporates a broad range of institutions, the banking system dominates. In 2007, the ratio of total banking system assets to GDP was 72.4 percent. The banking system is concentrated, however, in the three largest banks accounting for 41 percent of banking sector assets (Bawumia and Owusu-Danso, 2008). Financial sector stability is a priority and Ghana's financial soundness indicators have all improved in recent years (see Table 6).

Table 6

Financial Soundness Indicators

\begin{tabular}{|c|c|c|c|c|}
\hline & 2004 & 2005 & 2006 & 2007 \\
\hline \multicolumn{5}{|l|}{ Capital } \\
\hline Regulatory capital to risk-weighted assets & 10.0 & 12.6 & 13.2 & 14.8 \\
\hline Tier capital to risk-weighted assets & 8.8 & 11.3 & 11.7 & 13.6 \\
\hline \multicolumn{5}{|l|}{ Asset quality } \\
\hline $\begin{array}{l}\text { Nonperforming loans (NPLs) to total loans } \\
\text { (both net of accrued interest on NPLs }\end{array}$ & 12.8 & 10.2 & 6.3 & 5.4 \\
\hline Nonperforming loans (net of provisions and & & & & \\
\hline Accrued interest) to regulatory capital & 14.8 & 6.8 & 2.3 & 4.8 \\
\hline \multicolumn{5}{|l|}{ Earnings (Profitability) } \\
\hline Return on assets & 6.4 & 4.8 & 4.9 & 3.7 \\
\hline Return on equity & 49.6 & 38.1 & 40.0 & 35.8 \\
\hline Interest margin to gross income & 50.1 & 51.9 & 52.9 & 46.1 \\
\hline \multicolumn{5}{|l|}{ Liquidity } \\
\hline Ratio of net loans to total deposits & 54.9 & 66.7 & 71.8 & 78.6 \\
\hline Liquidity ratio & 74.3 & 68.7 & 61.1 & 53.4 \\
\hline Share of FX deposits in total deposits & 27.9 & 25.6 & 28.1 & 31.8 \\
\hline
\end{tabular}

Sources: Bawumia and Owusu-Danso (2008)

Indeed, despite the banking system's rapid growth-—led by credit expansion — the system is becoming increasingly sound; this is due to determined regulation, significant technological advances in the sector, and more forceful risk management by banks. At the same time, more aggressive lending has not impaired the capital adequacy of the banking system. In fact, the capital adequacy ratio reached 14.8 percent in 2007 from 9.5 percent in 2003. This was attributable to better loan recovery and rapid credit growth. To date, most of the new loans are performing. Ghana's financial reforms have increased the banking system's resilience to potential financial shocks. Moreover, the central bank is carefully monitoring the system's stability; it publishes a periodic financial stability report that is discussed by the central bank's monetary policy committee (Bawumia and Owusu-Danso, 2008). The Ghana Stock Exchange (GSE) has been a source of financing for corporations, and it remains small and illiquid. Trading is discontinuous; the total value traded is less than 1 percent of GDP, and turnover is below 4 percent.

Despite Ghana's recent achievements, the financial-sector reform agenda remains incomplete. Most important, the government must deepen secondary capital markets and reform small- and medium-sized finance, 
microfinance, and rural banking, as well as the pension and insurance systems. The authorities must also address cost inefficiencies, which are keeping interest rate spreads too high. They must also continuously adapt supervision to keep the financial sector stable in the context of rapid financial deepening and the emergence of new financial instruments. In addition, the supervisory frameworks in Ghana should be dynamic and proactive, to closely link and mirror the domestic financial sector and economic conditions for which it has been created. Supervisors should also be sensitive toward systemic risk, moral hazards, and adequate market integrity. Policymakers should structurally de-link the country's financial system of its presently overpoliticized policies to allow it to engage in the facilitation of the need for rapid economic transformation, intermediation, efficient capital mobilization, allocation, and good governance.

A clearer picture of the state of the financial system that resulted from the reform and from its linkage with the real sector will, however, emerge if the reform is further implemented with the past zeal and zest.

\section{CONCLUSION}

The liberalization of Ghana's financial system has included the relaxation of interest rate controls, relaxation on credit ceilings, partial privatization of government-owned banks, increased competition by permitting both private and foreign banks to establish in Ghana, restructuring public sector banks, and the development of capital and money markets.

Deregulating the prudential system to entail the revisions to the banking legislation enacted in the Banking Act of 1989 and NBFI Act in 1993 enticed the banks to introduce standard reporting and accounting procedures. The financial sector has been characterized by financial repression before the liberalization of the financial sector. This together with balance of payment deficits, overvalued exchange rate, inflationary pressure, and macroeconomic disequilibrium had almost dismantled the financial system. Since the liberalization, the performance of the public sector has been substantial, and healthy and easy to supervise. In addition, there have been several new entrants into the banking markets since the reforms.

The development in the banking system has shown a strong asset growth and improved profitability. This has strengthened the banks' capital position to absorb adverse shocks. The capital adequacy ratio which measured solvency of the banking industry continues to be high and remains well above the statutory threshold of 10 percent. Despite some gains from the reforms, it has not yet had a major impact on innovation in banking markets. There has been very little innovation in terms of the range of instruments and services provided. Although there have been occasional setbacks and institutional weakness in the accounting and legal systems remain, overall the financial liberalization strategy pursued in Ghana has been supportive of wider economic development.

\section{AUTHOR INFORMATION}

George Owusu-Antwi is a DBA student at Huizanga School of Business and Entrepreneurship, Nova Southeastern University and consultant at P.G. Consulting and Tax Service in Columbus Ohio. The author has had many years experience in banking and taxation. The holds three masters' degrees in the field of finance, economics and education. In 1992 the author obtained a Professional Banking Diploma certification from the American Institute of Banking in Bethesda Maryland. The author's research interest includes financial institutions and markets, corporate finance, international finance and macroeconomics.

\section{REFERENCES}

1. Adjetey, S.M A. 1978. The structure of the financial system in Ghana. Research Department, Bank of Ghana.

2. Alexander, W., Thomas, E., Baling, J. T., and Epoch, C. 1995. The adoption of indirect instruments on monetary policy. Occasional Paper 26. International Monetary Fund, Washington, DC.

3. Aryeetey, E. 1996. The formal financial sector in Ghana after the reforms. Working Paper, 86, London.

4. Aryeetey, E. and Gockel, F. 1990. Mobilizing domestic resources for capital formation in Ghana: The role of informal financial markets. AERO Research Paper, 3. Nairobi. 
5. Aryeetey, E. and Kanbur, R. 2005. Ghana's economy at half century: An overview of stability, growth and poverty. Institute of Statistical, Social \& Economic Research. University of Ghana, Legon.

6. Aryeetey, E. and Seini, W. 1992. An analysis of the transaction costs of lending in Ghana. Research Report Presented at African Economic Research Consortium Workshop. Nairobi, Kenya.

7. Aryeetey, E. and Senbet, L. W. 2004. Essential financial market reforms in Africa. Institute of Statistical, Social \& Economic Research. University of Ghana, Legon.

8. Bank of Ghana. 2004. Cost of banking in Ghana. An empirical assessment and implication Policy Brief. Research Department Bank of Ghana.

9. Bank of Ghana. 2005. Annual report. Accra, Ghana.

10. Bank of Ghana. 2007, May. Financial stability report, 7(2). Ghana.

11. Bawumia, M., Owusu-Danso, T., \& McIntyre, A. 2008. Ghana's reforms transform its financial sector. IMF Survey Magazine: Countries \& Region. International Monetary Fund, 1-4.

12. Bonaccorsi di Patti, E. and Hardy, D. C. 2005. Financial sector liberalization, bank privatization, and efficiency: Evidence from Pakistan. Journal of Banking \& Finance, 29, 2381-2406.

13. Brownbridge, M. 1998. The causes of financial distress in local banks in Africa and implications for prudential policy. UNCTAD Discussion Papers No. 132. Geneva: United Nations Conference on Trade and Development.

14. Brownbridge, M. and Gockel, A. F. 1996. The impact of financial sector policies on banking in Ghana. Research Department of Bank of Ghana.

15. Buchs, T. and Mathisen, J. 2005. Competition and efficiency in banking: Behavioral evidence from Ghana. IMF Working Paper WP/05/17. International Monetary Fund.

16. Clarke, G. R. G., Cull, R., and Peria, M. S. M. (2001). Does foreign bank penetration reduce access to credit in developing countries? Evidence from asking borrowers. World BankPolicy Research Working Paper No. 2716.

17. Clarke, G. R. G., Cull, R., and Shirley, 2005. Bank privatization in developing countries: A summary of lessons and findings. Journal of Banking \& Finance, 29, 1905-1930.

18. Daumont, R., Le Gall, F., and Leroux, F. 2004. Banking in Sub-Saharan Africa: What went wrong? IMF Working Paper. WP/04/55.

19. Emenuga, C. 2000. The outcome of financial sector reforms in West Africa. African voices on structural adjustment. www.idrc.ca/en/ev-56356-201-1-DO_TOPIC.html

20. Folkerts-Landau, D. and Lindgren, C. 1998. Toward a framework for financial stability. World Economic and Financial Surveys. International Monetary Fund. Washington, DC.

21. International Monetary Fund (IMF). 2003a. Ghana selected issues. Country Report No. 03/134. Washington, DC.

22. International Monetary Fund (IMF). 2003b. Ghana: Financial system stability assessment update, including reports on the observance of standards and codes on the following topics: Banking supervision, insurance regulation, and securities regulation. IMF Country Report No. 03/396. Washington, DC.

23. Johnston, B. and Brekk, O. P. 1991. Monetary control procedures and financial reforms: Approaches, issues and recent experience in developing countries. In P. Callier, ed., Financial Systems and Development in Africa. EDI Seminar Series. Washington, DC: World Bank.

24. Kapur, I, Hadjimichael, M. T., Hilber, P., Schiff, J. and Szymczak, P. 1991. Ghana: Adjustment and growth. www.imf.org/external/pubs/cat/longres.cfm?sk=64:0

25. La Porta, R., Lopez-de-Silanes, F., and Shleifer, A. 2002. Government ownership of banks. Journal of Finance, 57(2), 207-229.

26. Leite, S. P. 1982. Interest rate policy in West Africa. Staff Papers, 29(1). International Monetary Fund, 48-76.

27. Leith, J. C. and Söderling, L. 2000. Ghana: Long-term growth, atrophy, and recovery emerging in Africa. A report for the OECD development center project.

28. Mattoo, A., Rathindran, R., and Subramanian, A. 2006. Measuring services trade liberalization and its impact on economic growth: An illustration. Journal of Economic Integration, 2(1), 64-69.

29. McKinnon, R. I. 1973. Money and capital in economic development. Washington DC: The Brookings Institution.

30. Micco, A., Panizza, U., and Yanez, M. 2007. Bank ownership and performance. Does politics matter? Journal of Banking \& Finance, 31, 219-241. 
31. Nissanke, M. and Aryeetey, E. 1998. Financial integration and development in Sub-Saharan Africa. London and New York: ODI and Routledge.

32. Nissanke, M. and Aryeetey, E. 2006. Institutional analysis of financial market fragmentation in SubSaharan Africa. World Institute for Development Economics Research. Research Paper No. 2006/87, 126.

33. Otchere, I. 2005. Do privatized banks in middle- and low-income countries perform better than rival banks? An intra-analysis of bank privatization. Journal of Banking \& Finance, 29, 2067-2093.

34. Podpiera, R. 2004. Does compliance with Basel Core Principles bring any measurable benefits? IMF Working Paper 04/204. Washington, DC: International Monetary Fund.

35. Popiel, P. A. 1994. Financial systems in Sub-Saharan Africa: A comparative study. World Bank Discussion Papers 260, Africa Technical Department Series, Washington, DC.

36. Quartey, P. and Blankson, T. 2005. Household savings in Ghana: Does policy matter? In Aryeetey and Kanbur (eds.), Ghana's economy at half century: An overview of stability, growth and poverty. Institute of Statistical, Social \& Economic Research. University of Ghana, Legon.

37. Ranciere, R., Tornell, A., and Westermann, F. 2006. Decomposing the effects of financial liberalization: Crises vs. growth. Journal of Banking \& Finance, 30, 3331-3348.

38. Steel, W. F. and Andah, D. O. 2005. Rural and micro finance regulation in Ghana: Implications for development of the industry. In Aryeetey and Kanbur, eds., Ghana's economy at half century: An overview of stability, growth and poverty. Institute of Statistical, Social \& Economic Research. University of Ghana, Legon.

39. World Bank. 1986. Financial sector review. World Bank. Washington, DC.

40. World Bank. 1994. Ghana financial sector review: Bringing savers and investors together. World Bank Report No. 13423-GH. Washington, DC.

41. Ziorklui, S. Q. 2001. The impact of financial sector reforms on bank efficiency and financial deepening for savings mobilization in Ghana. African Economic Policy Discussion Paper 81. www.eagerproject.com/discussion81.shtml.

\section{NOTES}




\section{NOTES}

